\title{
Risk Factors of Leptospirosis in Klaten, Central Java
}

\author{
Maya Sofiyani'), Ruben Dharmawan ${ }^{2)}$, Bhisma Murti1) \\ 1)Masters Program in Public Health, Universitas Sebelas Maret \\ ${ }^{2)}$ Faculty of Medicine, Universitas Sebelas Maret
}

\begin{abstract}
Background: Leptospirosis a global public health issue, particullary in tropical and sub-tropical countries with high precipitation. WHO has estimated that the annual of Leptospirosis is 0.1 to 1 case/ 100,000 population in moderate non-endemic area, and 10 to 100 cases/100,000 population in humid and tropical endemic areas. Currently, Indonesia is a tropical country with the highest fatality rate of leptospirosis, ranging from $2.5 \%$ to $16.45 \%$ with an average of $7.1 \%$. It places Indonesia as the third country with the highest mortality attibutable to Leptospirosis. This study aimed to analyze the risk factors of Leptospirosis in Klaten, Central Java.

Subjects and Method: This was an analytic and observational study with case control design. The study was conducted in Klaten, Central Java, from October to November, 2017. A sample of 49 Leptospirosis cases and 101 non-diseased controls were selected for this study by fixed disease sampling. The independent variable were employment status, history of cuts, history of water excursion, use of personal protective equipment (PPE), house condition, environmental condition, presence of mouse or cattle, history of rain or flood. The dependent variable was Leptospirosis. The data were collected by questionnaire and analyzed by path analysis.

Results: The risk of Leptospirosis increased with history of cuts $(b=1.64$; CI 95\%=0.40 to 2.87; $\mathrm{p}=0.009)$, history of water excursion $(\mathrm{b}=1.98$; CI $95 \%=0.52$ to $3.43 ; \mathrm{p}=0.008)$, poor house condition ( $b=-1.92$; CI 95\% $=-3.08$ to $-0.77 ; \mathrm{p}=0.001)$, and poor environmental condition $(b=-$ 2.35; CI 95\% $=-3.48$ to $-1.23 ; \mathrm{p}<0.001)$. History of cuts increased with cattle-related work $(\mathrm{b}=1.79$; CI 95\%= 0.86 to 2.72; $\mathrm{p}<0.001)$ and absence of $\mathrm{PPE}(\mathrm{b}=-2.54$; CI 95\% $=-3.49$ to $-1.60 ; \mathrm{p}<0.001)$.

Conclusion: The risk of Leptospirosis increases with history of cuts, history of water excursion, poor house condition, and poor environmental condition. History of cuts increases with cattlerelated work and absence of PPE.
\end{abstract}

Keywords: risk factor, Leptospirosis

\section{Correspondence:}

Maya Sofiyani. Masters Program in Public Health, Universitas Sebelas Maret, Jl. Ir. Sutami 36 A, Surakarta, 57126, Central Java, Indonesia. Email: mayasofiani@rocketmail.com.

\section{BACKGROUND}

Leptospirosis is one of the neglected infectious diseases (NIDs) that are endemic infectious diseases in the poor or populations of farmers and workers associated with water and soil in developing countries (Al-orry et al., 2016). The World Health Organization estimates that the annual incidence of leptospirosis is 0.1 to 1 cases/ 100,000 people in moderate nonendemic areas, and 10 to 100 cases/ 100,000 people in humid, tropical, and endemic areas. The number of severe cases is reported to be about 300,000 to 500,000 annually worldwide, with a fatality rate of up to $30 \%$ (Word Health Organization, 2003).

The number of reported cases related to natural disasters and floods has increased with the most prominent outbreaks in Nicaragua (1995), Peru and Ecuador (1998), Orissa (1999), Malaysia (2000), Jakarta (2002), Mumbai (2000 and 2005), and the Philippines (2009). Not all countries consider leptospirosis as a public health threat that needs to be prevented as early as possible, perhaps because the 
Journal of Epidemiology and Public Health (2018), 3(1): 11-24

https://doi.org/10.26911/jepublichealth.2018.03.01.02

diagnostic ability of each country is different. Leptospirosis commonly affects farmers, plantation workers, miners/ sewers, slaughterhouse workers and the military (Schneider et al., 2013).

According to the International Leptospirosis Society (ILS), Indonesia is currently one of the tropical countries with relatively high leptospirosis deaths, ranging from $2.5 \%$ to $16.45 \%$ or an average of $7.1 \%$ and includes the third rank in the world for mortality rates (Word Health Organization, 2003).

Leptospirosis in Indonesia spread among others in West Java Province, Central Java Province, Lampung Province, Yogyakarta Special Region (DIY), South Sumatra Province, Bengkulu, Riau, West Sumatra, North Sumatra, Bali, NTB, South Sulawesi, North Sulawesi, Kalimantan East and West Kalimantan. The mortality rate due to leptospirosis in Indonesia is high, reaching $2.5 \%$ to $16.45 \%$, at the age of more than 50 years of death reaching $56 \%$. In some publications, the mortality rate is reported to be between $3 \%$ and $54 \%$ depending on the system of the infected organ (Zulkoni, 2011).

Data from the Ministry of Health in 2017, stated that provinces reporting cases of leptospirosis include DKI Jakarta, West Java, Central Java, DI Yogyakarta, East Java, Banten and South Kalimantan (Ministry of Health, 2017). Central Java province holds the highest number of cases in each year and increased in 2016 as many as 164 cases and reportedly died as many as 30 cases (CFR 18.29\%) (Kementerian Kesehatan RI, 2017).

Based on data from Central Java Provincial Health Book Book of 2016, leptospirosis cases and deaths in Central Java, in 2012 there were 129 cases and 20 deaths (CFR 15.50\%), in 2013 there were 156 cases and 17 deaths (CFR 10.90\%), in
2014 there are 207 cases and 34 deaths (CFR 16.42\%), in 2015 there are 149 cases and 24 deaths (CFR 16.10\%) and 2016 until the 2nd quarter there are 60 cases and 14 deaths (Central Java Dinkes, 2016). The spread of leptospirosis cases in Central Java is found in several regencies, namely Jepara, Pati, Demak, Semarang, Boyolali, Klaten, Sukoharjo, Karanganyar, Purworejo, Banyumas, and Cilacap.

Data from Klaten District Health Office, in 2015 found 26 cases of leptospirosis, in 2016 found 39 cases until in October 2017 found 41 cases of leptospirosis. Based on the results of investigations of extraordinary events in Klaten district shows that the spread of cases of leptospirosis in Klaten district is almost in all districts. The condition and behavior of the community is very potential for the occurrence of leptospirosis endemicity, the main source of transmission is strongly suspected to be around residential neighborhoods such as water puddles around the house, the presence of rats in and around the house and also some risk factors thought to contribute to the high incidence of leptospirosis in Klaten individual characteristics such as work, knowledge of leptospirosis itself, wound history, clean and healthy living behavior (PHBS), traveling history or water tourism (Klaten Health Office, 2016).

The high prevalence of Leptospirosis indicates that the problem is urgent that must be resolved by using an approach model capable of assessing various factors, either directly or indirectly. This study uses environmental approaches and individual characteristics to assess risk factors associated with Leptospirosis events.

Based on the problem, the researcher is interested to take the research problem with the title of risk factor related to the 
incidence of Leptospirosis in Klaten Regency.

\section{SUBJECTS AND METHOD \\ 1. Study design}

This was an analytic observational study with case control design. The study was conducted in Klaten, Central Java.

\section{Population and sample}

Source population were all leprosy patients who recorded by Klaten District Health Office from 2016 to 2017. A sample of 150 study subjects including 49 leprosy patients (case) and 101 not leprosy patients was selected for this study by fixed disease sampling.

\section{Study variables}

The dependent variable was leprosy. The independent variables were employment status, knowledge, the history of wound, history of water tourism, use of PPE, environment residence condition, physical house condition, and existence of rats or cattle.

\section{Operational definition of variable}

Leprosy incidence was defined as leprosy patients who diagnosed by doctors trough clinical examination and laboratory test in 2016 to 2017 and recorded by the Klaten District Health Office. The data were taken from medical record. The measurement scale was categorical, coded o for individual without leprosy and 1 for leprosy patient.

Employment was defined as the type of work that had the potential to develop leprosy in the two-week period prior to leprosy diagnosis. The data were collected by questionnaire. The measurement scale was categorical, coded o for low risk job and 1 for high risk job.

History of wound was defined as presence of minor or large injury in the study subject's body at least 2 weeks before diagnosed with leprosy. The data were collected by questionnaire. The measure- ment scale was categorical, coded o for did not have history of wound and 1 for had history of wound.

History of water tourism was defined as presence of water recreation history (especially fresh water such as pond, river, or spring) at least 2 weeks before diagnosed leprosy. The data were collected by questionnaire. The measurement scale was categorical, coded o for did not have history of water tourism and 1 for had history of water tourism.

Knowledge was defined as study subject's knowledge related to leprosy disease. The data were collected by questionnaire. The measurement scale was continuous, but for the purpose of data analysis it was transformed into dichotomous coded o for low knowledge and 1 for high knowledge.

Personal protective equipment (PPE) utilization was defined as action or prevention effort undertaken by the study subject to prevent leprosy transmission e.g. use PPE when working at risky occupation, contact with water/ soil/ animal tissues suspected of being contaminated by leprosy bacteria or in daily activities at least 2 weeks before leprosy diagnosis. The data were collected by questionnaire. The measurement scale was categorical, coded o did not use PPE and 1 for used PPE.

Physical house condition was defined as house construction that can prevent leprosy disease, including wall, floor, roof type, kitchen, and house cleanliness. The data were collected by observation sheet. The measurement scale was continuous, but for the purpose of data analysis it was transformed into dichotomous coded o for less condition and 1 for good condition.

Environment residence condition was defined as the circumstances surrounding the settlement of respondents covering the condition of garbage collection, the pre- 
Journal of Epidemiology and Public Health (2018), 3(1): 11-24

https://doi.org/10.26911/jepublichealth.2018.03.01.02

sence of standing water, close to the source of water, and the condition of the sewerage. The data were collected by observation sheet. The measurement scale was continuous, but for the purpose of data analysis it was transformed into dichotomous coded $\mathrm{O}$ for less condition and 1 for good condition.

The existence of rats or cattle was defined as the presence or absence of rats and pets in and around the house. The data were collected by questionnaire and observation sheet. The measurement scale was categorical.

History of rain/ flood was defined as the history of heavy rain and or flood in the region where the study subject lived at least 2 weeks before leprosy diagnosis. The data were collected by questionnaire. The measurement scale was categorical.

\section{Data Analysis}

The data of study subject's characteristics were analyzed using univariate. Bivariate analysis used Chi Square test, and multivariate analysis used path analysis. Path analysis used to determine the direct and indirect effect. Path analysis steps included model specification, model identification, model fit, parameter estimate, and model respecification.

\section{Research Ethics}

The research ethical clearance for this study was obtained from the Research Committee at Dr. Moewardi Hospital. Research ethics included informed consent, anonimity, and confidentiality.

\section{RESULTS \\ 1. Study subject's characteristic \\ Study subject's characteristic can be seen on the Table 1.}

Table 1. Distribution of study subject characteristics

\begin{tabular}{|c|c|c|c|c|c|}
\hline \multirow{2}{*}{ No } & \multirow{2}{*}{ Characteristics } & \multicolumn{2}{|c|}{ Case } & \multicolumn{2}{|c|}{ Control } \\
\hline & & $\mathbf{n}$ & $\%$ & $\mathbf{n}$ & $\%$ \\
\hline \multirow[t]{3}{*}{1.} & Sex & & & & \\
\hline & Male & 40 & 61.5 & 25 & 38.5 \\
\hline & Female & 9 & 10.6 & 76 & 89.4 \\
\hline \multirow[t]{3}{*}{2.} & Education & & & & \\
\hline & $<$ Senior high school & 34 & 47.9 & 37 & $52.1 \mathrm{~s}$ \\
\hline & $\geq$ Senior high school & 15 & 19.7 & 64 & 81.0 \\
\hline \multirow[t]{3}{*}{3.} & Employment & & & & \\
\hline & High risk & 36 & 62.1 & 22 & 37.9 \\
\hline & Low risk & 13 & 14.1 & 79 & 85.9 \\
\hline \multirow[t]{3}{*}{4.} & Knowledge & & & & \\
\hline & Low (score <18) & 35 & 60.3 & 23 & 39.7 \\
\hline & High $($ score $\geq 18)$ & 14 & 15.2 & 78 & 84.8 \\
\hline \multirow[t]{3}{*}{5.} & $\begin{array}{l}\text { Use of personal protective } \\
\text { equipment (PPE) }\end{array}$ & & & & \\
\hline & Used PPE & 11 & 11.5 & 85 & 88.5 \\
\hline & Not use PPE & 38 & 70.4 & 16 & 29.6 \\
\hline \multirow[t]{3}{*}{6.} & History of & & & & \\
\hline & Had history of wound & 36 & 61.0 & 23 & 39.0 \\
\hline & Did not have history of wound & 13 & $14 \cdot 3$ & 78 & $85 \cdot 7$ \\
\hline \multirow[t]{3}{*}{7.} & History of water tourism & & & & \\
\hline & Had history of water tourism & 14 & 51.9 & 13 & 48.1 \\
\hline & Did not have history of water tourism & 35 & 28.5 & 88 & 71.5 \\
\hline
\end{tabular}


Table 1 shows that 36 study subjects (62.1\%) in the case group had at-risk job of leprosy, while 79 study subjects (85.9\%) did not have a risky job of leprosy.

As many as $60.3 \%$ study subjects in the case group had low knowledge about leprosy and $70.4 \%$ did not use PPE. As many as $84.8 \%$ study subjects in the control group had high knowledge about leprosy and $88.5 \%$ used PPE.

As many as $85.7 \%$ study subjects in the control group did not have history of wound, $71.5 \%$ study subjects did not have history of water tourism.

\section{Bivariat analysis}

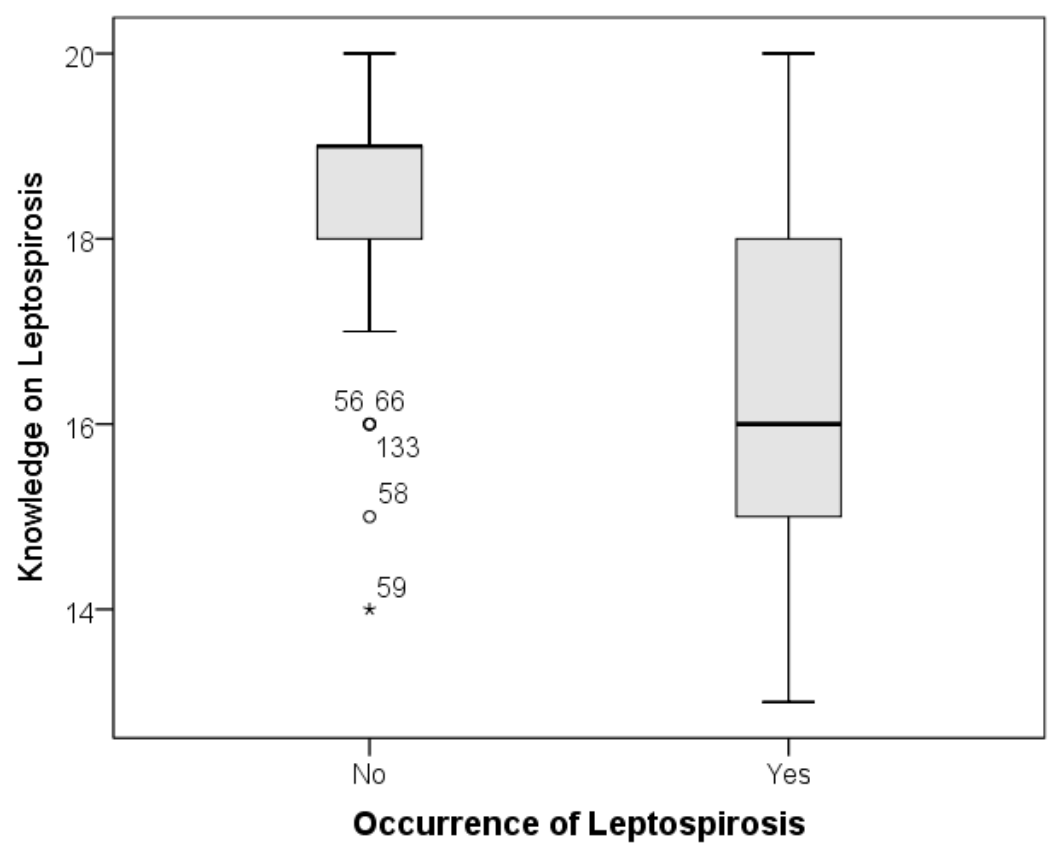

Figure 1. Difference in Mean of knowledge on Leptospirosis between the case and control groups of Leptospirosis

Figure 1 showed the difference in mean of knowledge on leptospirosis between the case and control groups of leptospirosis. Mean of knowledge was higher in the case group than control group, suggesting that knowledge is one of the important determinants of leptospirosis.

Figure 2 showed the difference in percent of persons using personal protective equipment (PPE) between the case and control groups of leptospirosis. The percent of persons using PPE was higher in the control group than the case group, suggesting that using PPE is one of the important determinants of leptospirosis.

Figure 3 showed percent of mouse or cattle presence between the case and control group of leptospirosis. The percent of mouse or cattle presence was higher in the case group than control group, suggesting that mouse or cattle presence is one of the important determinants of leptospirosis. 
Journal of Epidemiology and Public Health (2018), 3(1): 11-24

https://doi.org/10.26911/jepublichealth.2018.03.01.02

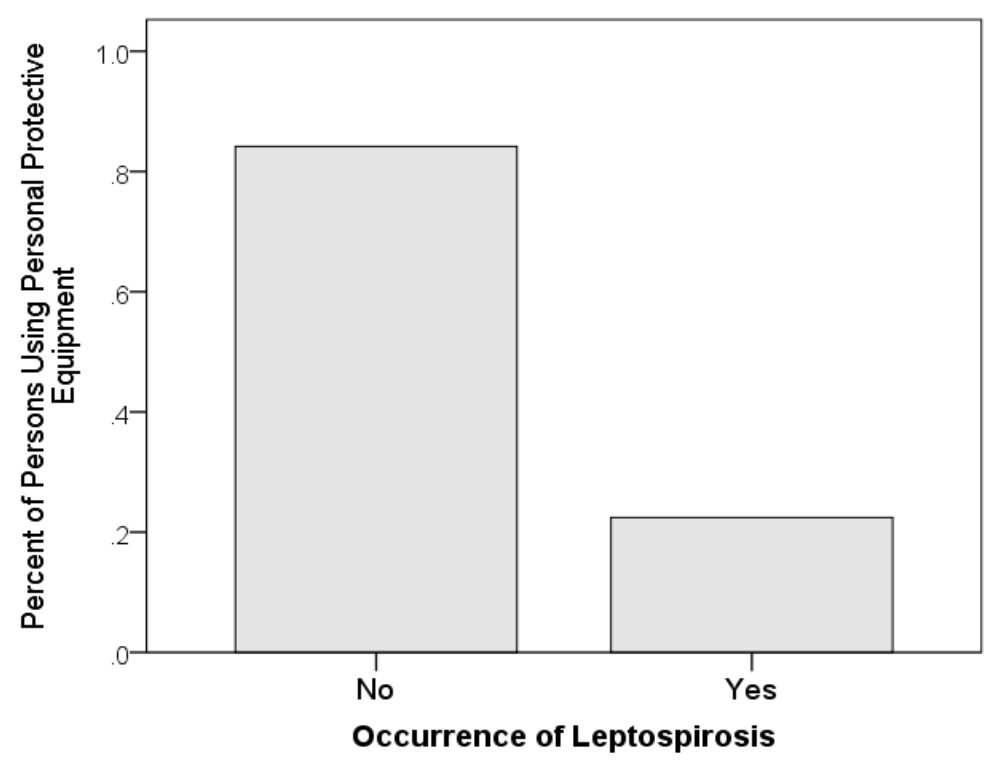

Figure 2. Difference in percent of persons using personal protective equipment between the case and control groups of Leptospirosis

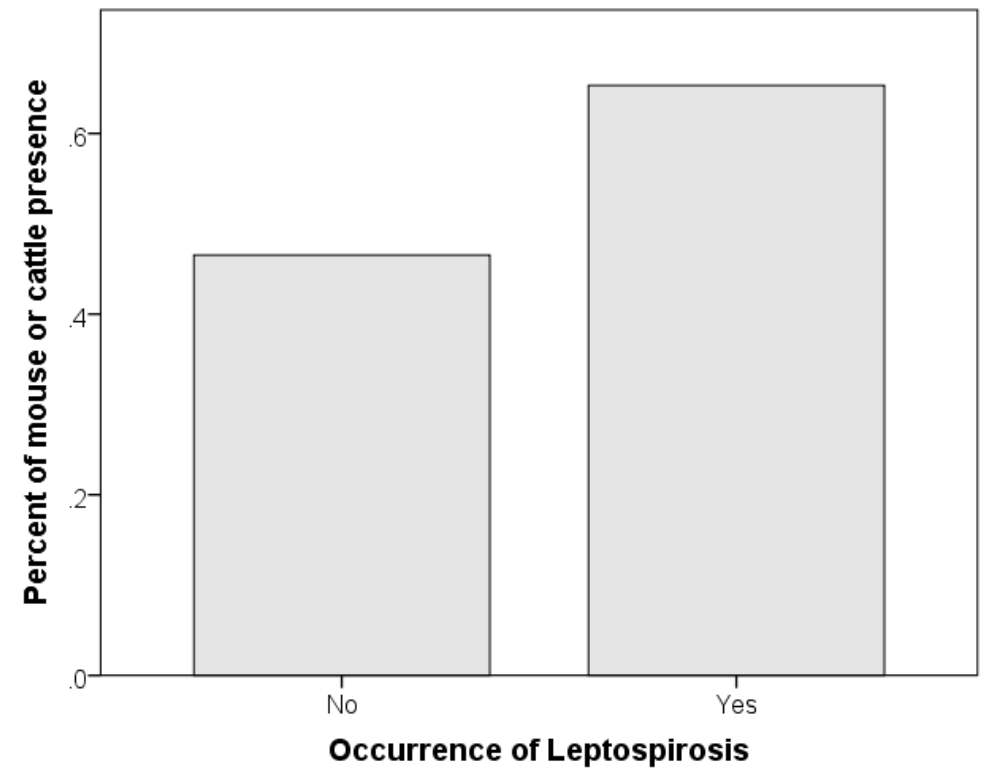

Figure 3. Percent of mouse or cattle presence between the case and control groups of Leptospirosis 


\section{Path analysis}

The data were analysis using Stata 13 program. The observed variables were 9, endogenous variables were 5 , exogenous variables were 4, and parameters were 11. Degree of freedom (df) value was 25.
Degree of freedom was over identified and path analysis can be done.

Structural model with estimation of path analysis showed in Figure 1. The results of path analysis showed in Table 2.

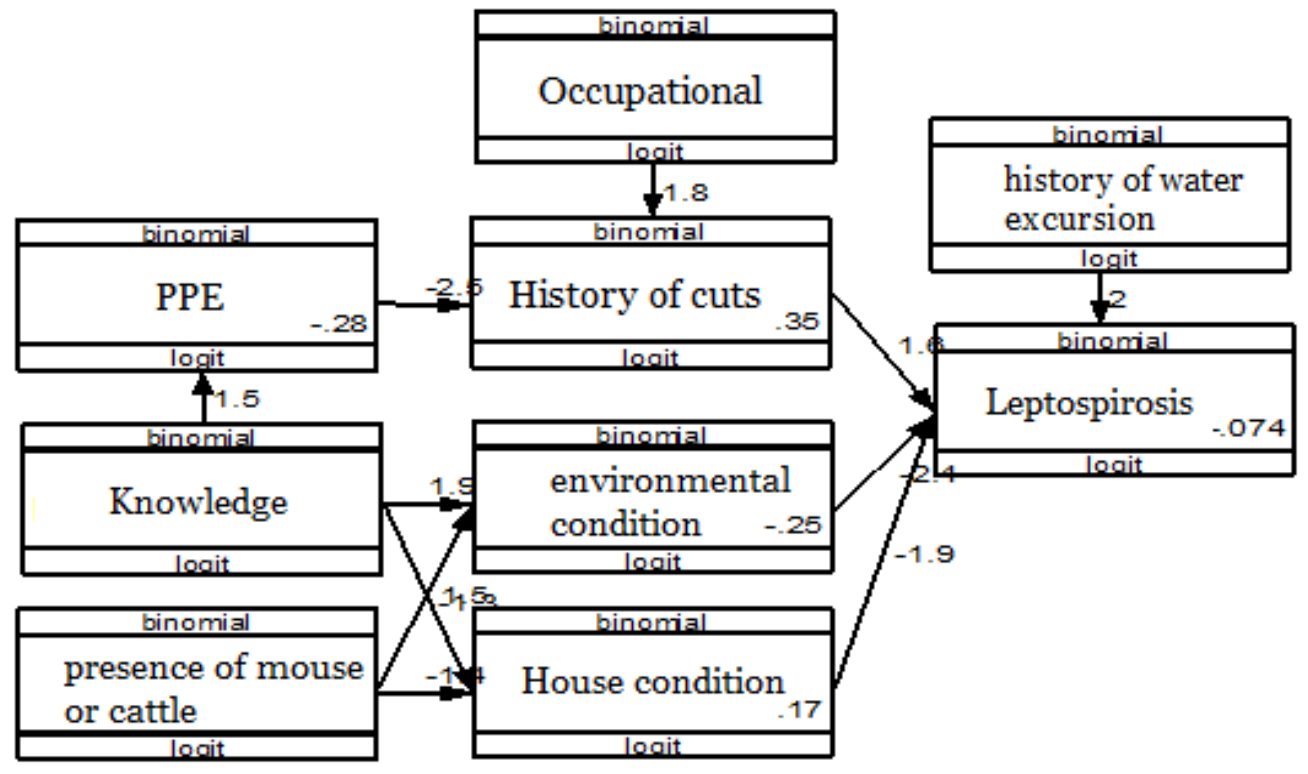

Figure 4. Structural model with estimation

Table 2 showed that the risk of leprosy increased with had a history of water tourism $(b=1.98 ; 95 \% \mathrm{CI}=0.52$ to $3.43 ; \mathrm{p}=$ 0.008) and had history of wound $(b=1.64$; CI $95 \%=0.40$ to $2.87 ; \mathrm{p}=0.009$ ).

The risk of leprosy decreased with good residence condition $(b=-2.35$; CI $95 \%=-3.48$ to $-1.23 ; \mathrm{p}<0.001)$ and good physical house condition $(b=-1.92$; CI $95 \%=-3.08$ to $-0.77 ; \mathrm{p}=0.001)$.

The chance of wound increased with employment. People who had high-risk employment had a higher chance of wound than people who had no high-risk employment $(b=1.79$; CI $95 \%=0.86$ to 2.72 ; $\mathrm{p}<0.001)$.

The risk of the existence of wound decreased with the use of personal pro- tective equipment $(\mathrm{b}=-2.54 ; \mathrm{CI} 95 \%=-3.49$ to $-1.60 ; \mathrm{p}<0.001)$.

Good residence condition increased with higher knowledge $(b=1.93$; CI 95\%= 1.15 to 2.70 ; $\mathrm{p}<0.001$ ).

House with rats or cattle decreased the environmental residence condition $(b=$ -1.29; CI 95\%=-2.05 to $-0.53 ; \mathrm{p}=0.001$ ).

Good physical house condition increased with better knowledge about leprosy $(b=1.47$; CI $95 \%=0.72$ to 2.21 ; $\mathrm{p}<0.001)$ and decreased with the existence of rats or cattle $(b=-1.41$; CI $95 \%=-2.15$ to $0.67 ; \mathrm{p}<0.001)$.

The use of personal protective equipment increased with better knowledge about leprosy $(b=1.49$; CI $95 \%=0.78$ to 2.20; $\mathrm{p}<0.001)$. 
Journal of Epidemiology and Public Health (2018), 3(1): 11-24

https://doi.org/10.26911/jepublichealth.2018.03.01.02

Table 2. The results of path analysis on the risk factor of Leprosy

\begin{tabular}{|c|c|c|c|c|c|c|}
\hline \multirow[b]{2}{*}{$\begin{array}{c}\text { Dependent } \\
\text { variable }\end{array}$} & \multirow{2}{*}{\multicolumn{2}{|c|}{ Independent variable }} & \multirow[b]{2}{*}{$\mathbf{b}$} & \multicolumn{2}{|c|}{$95 \% \mathrm{CI}$} & \multirow[b]{2}{*}{$\mathbf{p}$} \\
\hline & & & & $\begin{array}{c}\text { Lower } \\
\text { limit }\end{array}$ & $\begin{array}{l}\text { Upper } \\
\text { limit }\end{array}$ & \\
\hline \multicolumn{7}{|l|}{ Direct Effect } \\
\hline Leprosy & $\leftarrow$ & Had water tourism history & 1.98 & 0.52 & 3.43 & 0.008 \\
\hline Leprosy & $\leftarrow$ & Had history of the wound & 1.64 & 0.40 & 2.87 & 0.009 \\
\hline Leprosy & $\leftarrow$ & Good residence condition & -2.35 & -3.48 & -1.23 & $<0.001$ \\
\hline Leprosy & $\leftarrow$ & Good house condition & -1.92 & -3.08 & -0.77 & 0.001 \\
\hline \multicolumn{7}{|l|}{ Indirect Effect } \\
\hline $\begin{array}{l}\text { Had history of the } \\
\text { wound }\end{array}$ & $\leftarrow$ & Employment & 1.79 & 0.86 & 2.72 & $<0.001$ \\
\hline $\begin{array}{l}\text { Had history of the } \\
\text { wound }\end{array}$ & $\leftarrow$ & $\begin{array}{l}\text { Use of personal protective } \\
\text { equipment }\end{array}$ & -2.54 & -3.49 & -1.60 & $<0.001$ \\
\hline $\begin{array}{l}\text { Good residence } \\
\text { condition }\end{array}$ & $\leftarrow$ & High knowledge & 1.93 & 1.15 & 2.70 & $<0.001$ \\
\hline $\begin{array}{l}\text { Good residence } \\
\text { condition }\end{array}$ & $\leftarrow$ & The existence of rats / cattle & -1.29 & -2.05 & -0.53 & 0.001 \\
\hline $\begin{array}{l}\text { Good house } \\
\text { condition }\end{array}$ & $\leftarrow$ & High knowledge & 1.47 & 0.72 & 2.21 & $<0.001$ \\
\hline $\begin{array}{l}\text { Good house } \\
\text { condition }\end{array}$ & $\leftarrow$ & The existence of rats / cattle & -1.41 & -2.15 & -0.67 & $<0.001$ \\
\hline $\begin{array}{l}\text { Use of personal } \\
\text { protective } \\
\text { equipment } \\
\text { n Observation }=150 \\
\text { Log Likelihood }=-3\end{array}$ & 3.90 & High knowledge & 1.49 & 0.78 & 2.207 & $<0.001$ \\
\hline
\end{tabular}

\section{CONCLUSION}

\section{The association between history of water tourism and leprosy}

The result of this study indicated that the presence of water tourism history increased the risk of Leprosy. Activities that might increase the risk of Leprosy infection were social and recreational activities that encourage people to direct contact with the environment (especially water and soil) that has been contaminated with leptospirosis (International Leptospirosis Society, 2015).

Leprosy direct transmission caused by contact with bacteria through skin pores, mucous membranes, and slashed skin. Bath activities in river or lake are at higher risk of exposure to leptospira bacteria because of possible contact with infective animal urine. Swallowing contaminated water during diving is associated with high infection rates. Swimming or soaking the body into contaminated water is a common cause in a fifth of patients in the leprosy epidemic (International Leptospirosis Society, 2015).

\section{The association between history of wound and leprosy}

The result of this study indicated that the presence of wound history increased the risk of leprosy occurrence. Leptospira bacteria entered into the human body through the wound in the skin (Indonesian Health Ministry, 2013). This result is consistent with WHO (2004) which stated that leptospira bacteria into the human body through cut or abrasion on the skin, the mucous membrane of the mouth, nose, and eyes, blood, amniotic fluid, vagina, or tissue (WHO, 2004). (Sanford, 1994) explained that the pathway of leptospira bacteria into the human body is skin injured or abrasion, especially around the feet and eyelids, nose and mucous membranes. 
This study is also consistent with a study conducted by Suratman (2006) which stated that the history of the wound had 12.16 times higher risk for leprosy. Another study conducted by Cahyati (2009), showed that there was a correlation between wound history with leprosy occurrence in Sunan Kalijaga Hospital, Demak, Central Java.

\section{The association between residence condition and leprosy}

The results of this study indicate that poor environmental conditions increase the risk of Leptospirosis occurrence. The presence of waste or waste triggers the proliferation of rats and hence can trigger the risk of leptospirosis. Trash can also block the drainage system and exacerbate the risk of flooding. Many studies worldwide have confirmed that contact with waste and waste is a significant risk factor in the transmission of leptospirosis, particularly in urban and rural slums (Mythri, 2016).

The Ramadhani (2010) study shows that there is a correlation between poor dump conditions on leptospirosis (Ramadhani, 2010). the research (Priyanto et al., 2008) shows that there is a correlation between the presence of waste around the settlement and the incidence of leptospirosis and is at risk for exposure of 8.46 times compared with the condition of the nonexistent residential neighborhood.

Water flowing in the wild can be a source of infection (Soedin \& Syukran, 2007). Water that is inundated around the home environment can be a source of indirect transmission if the water has been contaminated with urine from infective animals (Rejeki et al, 2013). (Suratman, 2006), states that poor sewer conditions have a 5.58 times greater risk for severe leptospirosis than good sewer conditions. The role of the sewer as a pathway of leptospirosis transmission occurs when sewer water is contaminated by the urine of rats or other pets infected by Leptospira bacteria and the flow of sewer water is not smooth or stagnant so that it overflows into the environment around the house. Prabhakaran et al., In 2013 in Tamilnadu District India stated that, among cases of leptospirosis in urban areas, construction workers and people living near water bodies (rivers, irrigation canals, ditches and other) significantly ( $\mathrm{p}<\mathrm{0.001}$ ) associated with leptospirosis infection (Prabhakaran et al., 2014).

\section{The association between physical house condition and leprosy}

The results showed that poor home physical conditions increased the risk of Leptospirosis occurrence. circumstances in the house should be clean and orderly means the house arranged well, neatly, there is no pile of goods, the furniture neatly arranged and clean. Government Regulation no. 18 of 2012 states that the existence of a pile of goods can lead to breeding rats in the house (MOH, 2013).

Ramadani research (2010) suggests that the improper arrangement of home furnishings is related to the incidence of leptospirosis (Ramadhani, 2010). The physical condition of the house here also includes the condition of the floor, walls, and ceiling of the house. House with floor condition in plaster/ceramic, permanent house wall and kitchen and ceiling roof can prevent the increasing of rat population inside the house, also can block access of mouse into the house.

\section{The association between employ- ment status and leprosy through history of wound}

The results of this study indicate that work that is in direct contact with the source of infection increases the risk of Leptospirosis occurring through a history of injury. The magnitude of the risk depends on the prevalence of local leptospira intermediate, 
degree and frequency of exposure. Agricultural workers at risk for leptospirosis include rice-field workers, taro growers, banana growers, and sugarcane, corn and pineapple harvests (Al-Orry et al., 2016).

Agampodi et al., In Sri Lanka, states that wet-paddies and garbage workers are the work of risk for leptospirosis by contributing to leptospirosis cases in Sri Lanka of $89.7 \%$ and $27.6 \%$ (Agampodi et al., 2015). Jobs often tend to involve activities that result in exposure between host and disease agent, for example, in this case, a worker has scratches or abrasions resulting from his work at risk and then the wound is exposed to water or soil that has been contaminated by leptospires.

In the tropics of Queensland Australia, banana growers contribute to leptospirosis cases by two-thirds of all reported cases (Word Health Organization, 2003). Research on French Reunion Island shows the magnitude of risk in some leptospirosisrelated factor groups such as high-risk professions, contact with poultry, fishing or hunting, rural recreation (climbing or swimming) and gardening (Pages et al., 2014). Reis at al (2008) states that jobs that are in direct contact with the infected environment have a risk of 1.57 times for leptospirosis. This will get worse with the history of the wound and not be using personal protective equipment (APD) when in contact with the source of the infection (Reis et al., 2008).

\section{The association between personal protective equipment and leprosy through history of wound}

The results of this study indicate that the use of APD decreases the risk of leptospirosis through a history of injury. Behave hygiene by using personal protective equipment (APD) when on the move at risk for exposure to urine mice that cause leptospirosis, is one way to take preventive measures against the spread of leptospirosis. Hygienic behavior with PPE in this research is by using gloves, footwear (sandals/ shoes) at the time of cleaning ditch/ trench, clean up the trash or during daily activities (eg cleaning the house, working in rice fields or farms). Not using PPE can also cause injuries or scratches on the body, thus making it possible to be exposed to larger leptospirosis bacteria. This study is in line with the research conducted (Tunissea, 2011), stating that the majority of patients do not wear footwear and gloves as a protective of leptospirosis transmission.

Most of the study subjects suffered injuries to the legs and other body parts such as hands and fingers. The cause of the injury varies greatly, but in the interview process, the most common cause of injury is the activity of farming by not using the personal protective equipment. Most of the case groups are farmers, and when working most of them also do not use personal protective equipment so that in the old legs submerged by mud water causes injury. This wound ultimately becomes the pathway of leptospira bacteria into the body.

\section{The association between know- ledge and leprosy trough environ- ment residence condition}

The results of this study indicate that high knowledge decreases the risk of leptospirosis through residential conditions. Knowledge is a determinant factor of a person or society on health. Knowledge is a very important domain for the formation of one's actions. People who have a good knowledge of a disease that most likely will be able to prevent the occurrence of the disease. This theory states that knowledge affects against an incidence of disease including leptospirosis itself (Notoadmojo, 2003). 
Lack of knowledge about leptospirosis causes individuals cannot take precautions to avoid being infected by leptospirosis bacteria. Prabhu et al. (2014) in India, in 106 respondents who had a history of leptospirosis, 86 respondents $(81.1 \%)$ had never heard of prior leptospirosis (Prabhu et al., 2014). (Johnson et al., 2004) in Peru says two things that cause high rates of Leptospirosis in Peru are knowledge and who live close to water bodies/ rivers.

Knowledge directly affects environmental conditions, sufficient knowledge of leptospirosis will also have an impact on environmental conditions because there are behaviors that will always keep the environment clean so that it can prevent leptospirosis. (Finkmoore et al., 2013) identifies two potential causes for why people behave unhealthily, ie, less knowledge of leptospirosis and behaviors that increase risk.

\section{The association between the exist- ence of rats or cattle and leprosy trough residence condition}

The results of this study indicate that the presence of rats/ livestock increases the risk of leptospirosis through residential conditions. Transmission of leptospirosis can be through rats, pigs, cows, goats, horses, dogs, insects, birds, hedgehogs, bats and squirrels. In Indonesia, transmission occurs most often through rats. The rat's urine is carried by floods and then enter into the human body through the surface of the injured human skin, the mucous membrane of the eyes and nose. It could also be through a food or drink contaminated with a mouse urine infected with leptospires, then eaten and drunk by humans (Erviana, 2014).

The existence of rats/ cattle in the neighborhood will make the environmental conditions become dirty and unhealthy so it can be a rat habitat. (Finkmoore et al.,
2013) says that the community often piles the garbage around the house, because the distance between the house and the final waste collection site is very far away and the unavailability of the garbage transport service, so that in the end the waste will be piled up around the house and will invite the existence of rats that will be the cause of environmental conditions to be bad.

\section{The association between know- ledge and leprosy trough physical house condition}

The results showed that high knowledge reduced the risk of leptospirosis through home conditions. Grecie in Rio de Jeniero states that during the period of endemic indicators that indicate a significant correlation with leptospiral incidence is poverty. Poverty directly correlates with individual education and sanitation levels, such as knowledge levels, household waste disposal systems and provision of clean water sources in households (Gracie et al., 2014).

Lack of knowledge about leptospirosis will lead to the transmission of leptospirosis to humans more easily because of the absence of preventive measures. Therefore, health education to the community by the local government is indispensable in the early rarity of the decline in the incidence of leptospirosis in developing countries today (Brown et al., 2011). In the De Araujo et al (2013) study, there are many things we can do to prevent the breeding of mice around the house by using rat poison, closing rats access to the house, closing rodent holes and using mouse traps (Finkmoore et al., 2013).

10.The association between the existence of rats or cattle and leprosy trough physical house condition

The results showed that the presence of rats/ livestock increased the risk of leptospirosis occurrence through home conditions. Transmission of leptospirosis to hu- 
mans through rats is more likely, due to some types of mice whose habitats are located around human habitation. Priyanto's research shows that rat differentiation is related to leptospirosis risk (Priyanto et al., 2008).

Research conducted (Brown et al., 2011) in Jamaica states that the presence of livestock and pets such as dogs, cats, goats, cows and other related to the environmental conditions of the house. With the pets around the house will increase the risk of exposure to leptospira bacteria greater than those who do not have cattle at home. The presence of reservoirs (such as mice, dogs, cats, cows, goats) within the household environment decreases the quality of clean and healthy homes, thereby increasing the risk of leptospirosis (Reis et al., 2008). In his research, Reis also stated that the presence of vegetation in households increases the risk of 1.45 times and the presence of rats in households increases the risk of leptospirosis by 1.6 times. Contact with livestock without the use of personal protective equipment APD is also at risk for leptospirosis.

\section{The association between know- ledge and leprosy trough the use of personal protective equipment}

The results showed that the presence of rats/ livestock increased the risk of leptospirosis occurrence through home conditions. Transmission of leptospirosis to humans through rats is more likely, due to some types of mice whose habitats are located around human habitation. Priyanto's research shows that rat differentiation is related to leptospirosis risk (Priyanto et al., 2008).

Research conducted (Brown et al., 2011) in Jamaica states that the presence of livestock and pets such as dogs, cats, goats, cows and other related to the environmental conditions of the house. With the pets around the house will increase the risk of exposure to leptospira bacteria greater than those who do not have cattle at home. The presence of reservoirs (such as mice, dogs, cats, cows, goats) within the household environment decreases the quality of clean and healthy homes, thereby increasing the risk of leptospirosis (Reis et al., 2008). In his research, Reis also stated that the presence of vegetation in households increases the risk of 1.45 times and the presence of rats in households increases the risk of leptospirosis by 1.6 times. Contact with livestock without the use of personal protective equipment APD is also at risk for leptospirosis.

\begin{tabular}{c}
\hline REFERENCE \\
\hline Agampodi SB, Agampodi TC, Thalagala E, \\
Perera S, Chandraratne S, \& Fernando \\
S. (2010). IJPM Do People Know Ade- \\
quately about Leptospirosis? A Know- \\
ledge Assessment Survey in Post-out- \\
break Situation in Sri Lanka. Inter- \\
national Journal of Preventive Medi- \\
cine, 1(13), 158-163.
\end{tabular}

Al-orry W, Arahou M, Hassikou R, Quasmaoui A, Charof R, Mennane Z (2016). Leptospirosis: Transmission, Diagnosis and Prevention. International Journal of Innovation and Applied Studies, 15(3), 457-467.

Brown P, Mckenzie M, Pinnock M, Mcgrowder D (2011). Factors Associated with Leptospirosis among Associates in Jamaica. International Journal of Environmental and Medicine, 2(1): 47-57.

Cahyati W (2009). Hubungan Kebersihan Pribadi dan Riwayat Luka dengan Kejadian Leptospirosis. Jurnal Kesehatan Masyarakat (Journal of Public Health).

Depkes RI (2008). Pedoman Pengendalian Tikus. In Direktorat Jendral Pengen- 
dalian Penyakit dan Penyehatan Lingkungan. jakarta: Bakti Husada.

(2013). Petunjuk Teknis Upaya Pengendalian Penyakit dan Penyehatan Lingkungan dalam Penanggulangan Bencana. jakarta: Bakti Husada.

Dinkes Jateng (2016). Triwulan 2 tahun 2016 (Triwulan 2, Vol. 3511351). Semarang: Dinas Kesehatan Jateng.

Dinkes Klaten (2016). Profil Kesehatan Kabupaten Klaten 2016 (2016th ed.). Klaten.

Erviana A (2014). Studi Epidemiologi Kejadian Leptospirosis pada saat banjir di Kecamatan Cengkareng periode Januari-Februari 2014. https://doi.org/10.1017/CBO9781107415324.004.

Finkmoore B, Ribeiro G, Reis R, Felzemburgh R, Hagan E, Reis M, Costa F, et al. (2013). Knowledge, Attitudes , and Practices Related to Leptospirosis among Urban Slum Residents in Brazil. The American Society of Tropical Medicine and Hygiene, 88(2), 359-363. https://doi.org/10.4269/ajtmh.2012.12-0245

Gracie R, Barcellos C, Magalhães M, SouzaSantos R, \& Guimarães Barrocas PR. (2014). Geographical scale effects on the analysis of leptospirosis determinants. International Journal of Environmental Research and Public Health, 11(10): 10366-10383. https://doi.org/10.3390/ijerph111010366.

International Leptospirosis Society (2015). Leptospirosis. Word Health Organization. Retrieved from http://www.leptonet.net/.

Johnson MAS, Smith H, Joseph P, Gilman RH, Bautista CT, Campos KJ, Vinetz $\mathrm{JM}$, et al. (2004). Environmental Exposure and. Jornal of Emerging Infectious Disease, 10(6). Retrieved from www.cdc.gov/eid

Kementerian Kesehatan RI (2017). Data dan Informasi Profil Kesehatan Indonesia tahun 2016. In B. Hardhana, Yudianto, \& T. Soenardi (Eds.) (2016th ed.). jakarta: Kementerian Kesehatan RI.

Mandal (2008). Penyakit Infeksi (edisi ke 6). Jakarta: Airlanga.

Mythri B (2016). Leptospirosis - An Enigmatic Zoonosis. International Journal Cur Res Rev, 8(17).

Notoadmojo S (2003). Pendidikan dan Perilaku Kesehatan. Jakarta: Rineke Cipta.

Pages F, Polycarpe D, Dehecq J, Picardeau $\mathrm{M}$, Caillere N, Jaffar-Bandjee M, Filleul L, et al. (2014). Human leptospirosis on Reunion Island: Past and current burden. International Journal of Environmental Research and Public Health. https://doi.org/10.3390/ijerph110100968.

Prabhakaran SG, Shanmughapriya S, Dhanapaul S, James A, Natarajaseenivasan K (2014). Risk factors associated with rural and urban epidemics of leptospirosis in Tiruchirappalli District of Tamilnadu, India. Journal of Public Health, 22(4), 323-333. https://doi.org/10.1007/s10389-0140611-1.

Prabhu N, Meera J, Bharanidharan G, Natarajaseenivasan $\mathrm{K}$, Ismail $\mathrm{M}$, Uma A (2014). Knowledge, Attitude and Practice towards Leptospirosis among municipal workers in Tiruchirapalli, India. Journal of Public Health 2(3).

Priyanto A, Hadisaputro S, Santoso L, Gasem H, Adi S (2008). FaktorFaktor Risiko Yang Berpengaruh Terhadap Kejadian Leptospirosis (Studi Kasus di Kabupaten Demak). Diponegoro University, 1-11.

Ramadhani T (2010). Kondisi Lingkungan yang tidak Sehat Berisiko terhadap Kejadian Leptospirosis (studi kasus di 
Kota Semarang). P2B2 Banjarnegara.

Reis RB, Ribeiro GS, Felzemburgh RDM, Santana FS, Santos C, Ravines RR, Ko AI, et al. (2008). Impact of Environment and Social Gradient on Leptospira Infection in Urban Slums. International Journal of Neglected Tropical Disease, 2(4): 11-18. https://doi.org/10.1371/journal.pntd.oooo228

Rejeki DSS, Nurlaela S, Octaviana D (2013). Pemetaan dan Analisis Faktor Risiko Leptospirosis. Kesmas: Jurnal Kesehatan Masyarakat Nasional: 179. https://doi.org/10.21109/kesmas.voio.397.

Sanford J (1994). Leptospirosis. (Isselbacher K,BraunwaldE, MartinJ, FauciA, \& KasperD, Eds.) (13th ed.). New York: Harrison's Principle of Internal Medicine.

Schneider MC, Jancloes M, Buss DF, Aldighieri S, Bertherat E, Najera P, Org E, et al. (2013). Leptospirosis: A Silent Epidemic Disease. International Journal of Environmental Research and Public Health, 10, 72297234. https://doi.org/10.3390/ijerph10127229.

Soedin K, Syukran OL (2007). Leptospirosis. (Soeparman \& Waspadji S. Eds.) (3rd ed.). jakarta: Balai Kesehatan FKUI.

Suratman (2006). Analisis Faktor Risiko
Lingkungan Dan Perilaku Yang Berpengaruh Terhadap Kejadian Leptospirosis Berat Di Kota Semarang. Universitas Stuttgart, 1-143. https://doi.org/47 (1982-2005).

Tunissea A (2011). Analisis Spasial Faktor Risiko Lingkungan Pada Kejadian Leptospirosis di Kota Semarang (sebagai sistem kewaspadaan dini). Tesis. Universitas Diponegoro Semarang.

WHO (2004). Leptospirosis. Geneva: Word Health Organization.

Widoyono (2008). Penyakit Tropis: Epidemiologi, Penularan, Pencegahan dan Pemberantasa. jakarta: Eirlannga.

Wiwanitkit V (2006). A Note From A Survey Of Some Knowledge Aspects of Leptospirosis Among A Sample of Rural Villagers In The Highly Endemic Area, Thailand. The International Electronic Journal of Rural and Remote Health Research, Education, Practice and Policy, 6: 526. Retrieved from http://rrh.deakin.edu.au

Word Health Organization (2003). Human leptospirosis: guidance for diagnosis, surveillance and control. In T. Coleman \& I. Struiksma (Eds.), International Leptospirosis Society. Word Health Organization. Retrieved from www.who.int/en/

Zulkoni A. (2011). Parasitologi. Yogyakarta: Nuha Medika. 